\title{
Integrated Farming System in Chickballapura District- A Method to Improve Livelihood Security of Farmers
}

\author{
V. L. Madhu Prasad, S. Chandrashaker and S. Sujay Kumar* \\ Department of Sericulture, $U A S(B)$, India \\ *Corresponding author
}

\section{A B S T R A C T}

\section{Keywords}

Integrated Farming System, Scheduled Caste and

Livelihood Security

Article Info

Accepted:

20 December 2020

Available Online:

10 January 2021
The study was conducted in purposively selected three taluks of Chickballapura district. Total sample of 271respondents were purposively selected for the study. The data were collected by using structured interview schedule and analyzed by using appropriate statistical tools It was observed that livelihood security of respondents in less satisfied category decreased by 10.33 per cent, satisfied category increased by 1.85 per cent and highly satisfied category improved by 8.48 per cent after implementation of the project. Out of seven dimensions it was observed that employment security increased by 39.35 percent, living amenities increased by 30.82 per cent, coping strategies against stress increased by 30.75 per cent, ecological security increased by 30.00 percent, economic efficiency increased by 28.95 per cent, assets increased by 25.71 per cent and social equitability increased by 24.41 per cent. Overall livelihood security improved by 30.23 per cent increase after implementation of project. The average yield of ragi increased by 46.15 per cent, groundnut increased by 33.33 per cent. The livestock components (cow and sheep) generate 345 mandays employment per year and provide additional net income of Rs. 60000. In 2018 reported that the average gross income of Rs. 103264 from both crop and livestock enterprises of IFS against Rs. 6956 before implementation of the project. In total respondents could realize about Rs. 70300 net profit by adopting intercropping and livestock components in IFS. As such, for every one rupee investment under IFS they are getting 3.13 rupee income. The characteristics such as land holding, cropping pattern, livestock possession, cosmopoliteness, innovativeness, extension participation, social participation, management orientation, training undergone, willingness towards IFS and access to resources exhibited significant relationship with farmers livelihood security. Hence, the concerned development departments should organize the demonstrations, trainings, field days, exposure visits etc., to educate the farmers about IFS. The positive and significantly related characteristics need to be considered while selecting farmers for the extension educational programmes to enhance their livelihood security through IFS.

\section{Introduction}

India is predominantly an agriculture dependent nation where almost 58.00 per cent of its population engaged in agriculture production. The geographical area of the country is 328.7 million hectares. Net sown area is 141 million hectares and gross cropped 
area is 190 million hectares. It is anticipated that the land available for cultivation in 2050 would be 137 million hectares. With the gradual increase in population resulting in continuous fragmentation of cultivable land within the family. The number of small farm holdings has risen from 83.2 per cent in the year 2005-06 to 85.00 per cent in the year 2010-11. The average size of the Indian farmland shrank by over six per cent between 2010-11 and 2015-16, with operational holding in the country dropping to 1.08 hectares from 1.15 hectares in 2010-11. With land holding getting smaller, the share of small and marginal holdings in the country has risen to 86.21 per cent of total operational holding in 2015-16, which comes to around 126 million, as against 84.97 per cent in 2010-11(Anon., 2018). Most of the scheduled caste farmers comes under small and marginal category of land holding and agricultural labourers. The concept of livelihood is rapidly gaining acceptance as a valuable means of understanding the factors that influence people's lives and well - being. It is comprised of capacities, assets, activities and coping strategies to overcome crisis required for means of living. Livelihood is the means people use to support themselves, to survive and to prosper. It is an outcome of how and why people organize to transform the environment to meet their needs through technology, labour, power, knowledge and social relations.

ICAR and State Agricultural Universities are continuously putting lot of efforts for at increasing the productivity of different components of farming system i.e. crops, horticultural crops, livestock, poultry, apiculture, sericulture, mushroom cultivation, organic manures production, bio-gas etc. individually but lacking in their integration by following farming system approach. The integration is made in such a way that product of one component should be the input for other enterprises with high degree of complimentary effects on each other. The University of Agricultural Sciences, Bangalore implemented the project entitled "Livelihood Improvement of Scheduled Caste (SC) Farm Families through Integrated Farming System (IFS)" with the financial support from the Government of Karnataka under Scheduled Caste Sub Plan (SCSP) during the period from 2014-15- to 2018-19. The project aims at sustainable development of agriculture among the farmers by bringing them to mainstream and also efficient management of soil, water, crop and IPM practices in crop husbandry. Further, it integrates dairy, poultry, sheep, piggery, fishery, sericulture, agro-forestry and other related enterprises with crop husbandry which increases the overall net income. With this background, the present study is conceptualized to following objectives

1. To know the personal and sociopsychological characteristics of respondents

2. To measure the livelihood security of SC farmers practicing Integrated Farming System

3. To analyze the impact of Integrated Farming System on development of SC farmers

4. To know the relationship between personal and socio-psychological characteristics of respondents with their livelihood security

\section{Materials and Methods}

The study was conducted in purposively selected Chickballapura district of Karnataka based on the implementation of the project entitled "Livelihood Improvement of Scheduled Caste (SC) Farm Families through Integrated Farming System (IFS)".Three taluks were selected namely Chintamani, Bagepalli and Chickballapuraand two Grama 
Panchayats from each taluk and 3 to 4 villages/ grama panchayat were selected based on maximum number of SC farm families. All the farm families having land holding 1.00 to 5.00acres land were considered as beneficiaries (respondents) of the project. Total sample of 271 respondents were purposively selected for the study. The data were analyzed by using mean, percentage, standard deviation, correlation coefficient and regression coefficient. Livelihood security measured by using five point continuum scale developed by Mamathalakshmi (2013) with slight modification before and after implementation of the project.

\section{Results and Discussion}

It was observed in Table 1 indicates that the majority respondents belong to medium level of education, cropping pattern, livestock possession, mass media exposure, extension participation, training undergone and access to resources. This finding can be explained on the basis of the fact that the rural social environment was the major cause for such trend. As the rural people are still traditional bound, they don't prefer to continue their children education, the distance of higher study centres from villages also might have prevented the parents from providing higher education to their children. Medium level of cropping pattern and livestock possession was observed due to the reason that through project seed material, planting materials and animal component like cow and sheep were supplied free of cost to respondents. Participation in extension activities and development programmes provided opportunities for them to improve their knowledge about IFS technologies and to be rational in decision making and in adoption of new IFS technologies. Training provided opportunities to improve their knowledge and skills about IFS. Under the project ample opportunity was given to respondents to undergo training on various aspects of IFS. The respondents practicing IFS have taken up more than one enterprises which includes crop production, dairy, sheep rearing, poultry birds, crop rotation etc., which results medium level of access to resources.

The study conferred that high level of social participation, management orientation, level of aspiration, risk orientation, participation in development program and willingness towards IFS. Nowadays villages have more number of social organisations such as Grama Panchayat, Taluk Panchayat, Farmer Cooperatives etc., might have made them to take part in it. Further, the reservation policy in these organizations might have enhanced their participation in social organizations. Through the project, respondents were exposed to different components of IFS through training programs, result demonstrations and visits to Krishimela which improved their managerial skill, social participation and aspiration level. Further,low level of cosmopoliteness and scientific orientation. It could be due to the fact that the village does not had better road connectivity and transport facilities, which enabled the respondents not to visit city to sell their produce, to purchase inputs, to meet the officers of developmental departments / project staff to seek advice or to derive benefits as well as for domestic purposes and entertainment. Raksha (2012), JayantaRoy (2012). Mamathalakshmi Rokonuzzaman (2013), Sujay Kumar (2018) and Harshitha (2018).

A critical appraisal of Table 2 indicates that livelihood security of respondents in less satisfied category decreased by 10.33 per cent, satisfied category increased by 1.85 per cent and highly satisfied category improved by 8.48 per cent after implementation of the project. 
The results showed in Table 3 indicate the improvement in different dimensions of livelihood security after the implementation of IFS project. It was observed that employment security increased by 39.35 percent, living amenities increased by 30.82 per cent, coping strategies against stress increased by 30.75 per cent, ecological security increased by 30.00 percent, economic efficiency increased by 28.95 per cent, assets increased by 25.71 per cent and social equitability increased by 24.41 per cent. Overall, 30.23 per cent increase was noticed after implementation of project.

Table.1 Distribution of respondents according to their personal, social, economic and psychological variables $(\mathrm{N}=271)$

\begin{tabular}{|c|c|c|c|c|}
\hline Sl. No & Characteristics & Category & Number & Per cent \\
\hline \multirow[t]{3}{*}{1.} & \multirow[t]{3}{*}{ Education } & Low & 55 & 20.22 \\
\hline & & Medium & 163 & 59.93 \\
\hline & & High & 54 & 19.85 \\
\hline \multirow[t]{3}{*}{2.} & \multirow[t]{3}{*}{ Land holding } & Marginal & 118 & 43.38 \\
\hline & & Small & 84 & 30.88 \\
\hline & & Big & 70 & 25.74 \\
\hline \multirow[t]{3}{*}{3.} & \multirow[t]{3}{*}{ Cropping pattern } & Low & 69 & 25.37 \\
\hline & & Medium & 103 & 37.87 \\
\hline & & High & 100 & 36.76 \\
\hline \multirow[t]{3}{*}{4.} & \multirow[t]{3}{*}{ Livestock possession } & Low & 83 & 30.51 \\
\hline & & Medium & 101 & 37.13 \\
\hline & & High & 88 & 32.35 \\
\hline \multirow[t]{3}{*}{5.} & \multirow[t]{3}{*}{ Cosmopoliteness } & Low & 99 & 36.40 \\
\hline & & Medium & 82 & 30.15 \\
\hline & & High & 91 & 33.46 \\
\hline \multirow[t]{3}{*}{6.} & \multirow[t]{3}{*}{ Innovativeness } & Low & 105 & 38.60 \\
\hline & & Medium & 80 & 29.41 \\
\hline & & High & 87 & 31.99 \\
\hline \multirow[t]{3}{*}{7.} & \multirow[t]{3}{*}{ Mass media exposure } & Low & 91 & 33.46 \\
\hline & & Medium & 108 & 39.71 \\
\hline & & High & 73 & 26.84 \\
\hline \multirow[t]{3}{*}{8.} & \multirow{3}{*}{ Extension participation } & Low & 87 & 31.99 \\
\hline & & Medium & 109 & 40.07 \\
\hline & & High & 76 & 27.94 \\
\hline \multirow[t]{3}{*}{9.} & \multirow[t]{3}{*}{ Social participation } & Low & 72 & 26.47 \\
\hline & & Medium & 96 & 35.29 \\
\hline & & High & 104 & 38.24 \\
\hline \multirow{3}{*}{10.} & \multirow{3}{*}{$\begin{array}{l}\text { Scientific orie } \\
\text { ntation }\end{array}$} & Low & 109 & 40.07 \\
\hline & & Medium & 88 & 32.35 \\
\hline & & High & 75 & 27.57 \\
\hline \multirow[t]{2}{*}{11.} & \multirow[t]{2}{*}{ Management orientation } & Low & 72 & 26.47 \\
\hline & & Medium & 96 & 35.29 \\
\hline
\end{tabular}




\begin{tabular}{|c|c|c|c|c|}
\hline & & High & 104 & 38.24 \\
\hline \multirow[t]{3}{*}{12.} & \multirow[t]{3}{*}{ Level of aspiration } & Low & 92 & 33.82 \\
\hline & & Medium & 83 & 30.51 \\
\hline & & High & 97 & 35.66 \\
\hline \multirow[t]{3}{*}{13.} & \multirow[t]{3}{*}{ Risk orientation } & Low & 90 & 33.09 \\
\hline & & Medium & 76 & 27.94 \\
\hline & & High & 106 & 38.97 \\
\hline \multirow[t]{3}{*}{14.} & \multirow[t]{3}{*}{ Training undergone } & Low & 54 & 19.85 \\
\hline & & Medium & 164 & 60.29 \\
\hline & & High & 54 & 19.85 \\
\hline \multirow[t]{3}{*}{15.} & \multirow{3}{*}{$\begin{array}{l}\text { Participation in the } \\
\text { developmental programmes }\end{array}$} & Low & 54 & 19.85 \\
\hline & & Medium & 85 & 31.25 \\
\hline & & High & 133 & 48.90 \\
\hline \multirow[t]{3}{*}{16.} & \multirow[t]{3}{*}{ Willingness towards IFS } & Low & 93 & 34.19 \\
\hline & & Medium & 78 & 28.68 \\
\hline & & High & 101 & 37.13 \\
\hline \multirow[t]{3}{*}{17.} & \multirow[t]{3}{*}{ Access to extension personnel } & Low & 96 & 35.29 \\
\hline & & Medium & 81 & 29.78 \\
\hline & & High & 95 & 34.93 \\
\hline \multirow[t]{3}{*}{18.} & \multirow[t]{3}{*}{ Access to resources } & Low & 54 & 19.85 \\
\hline & & Medium & 188 & 69.12 \\
\hline & & High & 30 & 11.03 \\
\hline
\end{tabular}

Table.2 Distribution of respondents according to their livelihood security $(\mathrm{N}=271)$

\begin{tabular}{|r|l|c|c|c|c|c|}
\hline Sl. No. & \multicolumn{1}{|c|}{ Category } & \multicolumn{2}{c|}{ Before } & \multicolumn{2}{c|}{ After } & Change in \\
\cline { 3 - 7 } & & Number & Pe cent & Number & Per cent & Per \\
\hline 1. & Less satisfied & 118 & 43.54 & 90 & 33.21 & -10.33 \\
\hline 2. & Satisfied & 79 & 29.15 & 84 & 31.00 & 1.85 \\
\hline 3. & Highly Satisfied & 74 & 27.31 & 97 & 35.79 & 8.48 \\
\hline & Total & 271 & 100.00 & 271 & 100.00 & \\
\hline
\end{tabular}

Table.3 Dimension-wise analysis of livelihood security pattern among respondents (N=271)

\begin{tabular}{|c|l|c|c|c|}
\hline \multirow{2}{*}{ SI. No. } & \multicolumn{1}{|c|}{ Dimension } & \multicolumn{2}{c|}{ Mean Value } & \multirow{2}{*}{ Percentage in increase } \\
\cline { 3 - 4 } & & Before & After & \\
\hline $\mathbf{1}$ & Assets & 1050 & 1320 & 25.71 \\
\hline $\mathbf{2}$ & Living amenities & 380 & 1282 & 30.82 \\
\hline $\mathbf{3}$ & Economic efficiency & 640 & 490 & 28.95 \\
\hline $\mathbf{4}$ & Ecological security & 721 & 832 & 30.00 \\
\hline $\mathbf{5}$ & Social equitability & 683 & 893 & 24.41 \\
\hline $\mathbf{6}$ & Coping strategies against stress & 948 & 1321 & 30.75 \\
\hline $\mathbf{7}$ & Employment security & 5402 & 7035 & 39.35 \\
\hline & Overall Livelihood Security & & & 30.23 \\
\hline
\end{tabular}


Table.4 Relationship between independent variables with the attitude of IFS farmers (N=271)

\begin{tabular}{|c|l|c|}
\hline Sl. No. & \multicolumn{1}{|c|}{ Independent variables } & Correlation co-efficient (r) \\
\hline $\mathbf{1 .}$ & Education & -0.067 \\
\hline $\mathbf{2 .}$ & Land holding & $0.460^{* *}$ \\
\hline $\mathbf{3 .}$ & Cropping pattern & $-0.310^{* *}$ \\
\hline $\mathbf{4 .}$ & Livestock possession & $0.577^{* *}$ \\
\hline $\mathbf{5 .}$ & Csmopoliteness & $0.133^{*}$ \\
\hline $\mathbf{6 .}$ & Innovativeness & $0.484^{* *}$ \\
\hline $\mathbf{7 .}$ & Mass media exposure & 0.082 \\
\hline $\mathbf{8 .}$ & Extension participation & $0.581^{* *}$ \\
\hline $\mathbf{9 .}$ & Social participation & $0.380^{* *}$ \\
\hline $\mathbf{1 0}$ & Scientific orientation & 0.090 \\
\hline $\mathbf{1 1 .}$ & Management orientation & $0.167^{* *}$ \\
\hline $\mathbf{1 2}$. & Level of aspiration & 0.043 \\
\hline $\mathbf{1 3}$. & Risk orientation & 0.058 \\
\hline $\mathbf{1 4}$ & Training undergone & $0.502^{* *}$ \\
\hline $\mathbf{1 5}$. & Participation in the developmental programme & 0.002 \\
\hline $\mathbf{1 6 .}$ & Willingness towards IFS & $0.157^{* *}$ \\
\hline $\mathbf{1 7 .}$ & Access to extension personnel & 0.060 \\
\hline $\mathbf{1 8}$. & Access to resources & $0.181^{* *}$ \\
\hline
\end{tabular}

NS: Non-Significant; *: Significant at 5\% level; **: Significant at $1 \%$ level

Table.5 Multiple regression analysis of independent variables of respondents with their attitude towards IFS $(\mathrm{N}=271)$

\begin{tabular}{|c|l|c|c|c|}
\hline Sl. No & \multicolumn{1}{|c|}{ Variables } & $\begin{array}{c}\text { Regression } \\
\text { coefficient (b) }\end{array}$ & $\begin{array}{c}\text { Std. Error of } \\
\text { regression } \\
\text { co-efficient } \mathbf{S E}_{\mathbf{b}} \text { ) }\end{array}$ & 't' value \\
\hline $\mathbf{1}$ & Education & -.077 & .198 & -0.389 \\
\hline $\mathbf{2}$ & Land holding & .799 & .368 & $2.169^{*}$ \\
\hline $\mathbf{3}$ & Cropping pattern & -.024 & .022 & -1.128 \\
\hline $\mathbf{4}$ & Livestock possession & .302 & .075 & $4.041^{* *}$ \\
\hline $\mathbf{5}$ & Cosmopoliteness & .331 & .127 & $2.612^{*}$ \\
\hline $\mathbf{6}$ & Innovativeness & .393 & .156 & $2.512^{*}$ \\
\hline $\mathbf{7}$ & Mass media exposure & -.029 & .111 & -0.266 \\
\hline $\mathbf{8}$ & Extension participation & .676 & .172 & $4.613^{* *}$ \\
\hline $\mathbf{9}$ & Social participation & -.005 & .083 & $2.064^{*}$ \\
\hline $\mathbf{1 0}$ & Scientific orientation & -.004 & .104 & -0.048 \\
\hline $\mathbf{1 1}$ & Management orientation & -.041 & .085 & -0.050 \\
\hline $\mathbf{1 2}$ & Level of aspiration & -.004 & .061 & -0.676 \\
\hline $\mathbf{1 3}$ & Risk orientation & .507 & .072 & -0.051 \\
\hline $\mathbf{1 4}$ & Training undergone & -.355 & .229 & $2.214^{*}$ \\
\hline $\mathbf{1 5}$ & Participation in the & & .273 & -1.299 \\
\hline & programme & .027 & & \\
\hline $\mathbf{1 6}$ & Willingness towards IFS & -.007 & .067 & 0.408 \\
\hline $\mathbf{1 7}$ & Access to extension personnel & .067 & .065 & -0.115 \\
\hline $\mathbf{1 8}$ & Access to resources & .021 & $3.170^{* *}$ \\
\hline
\end{tabular}

$\mathrm{R} 2=0.553, \mathrm{~F}=17.586^{* *}$; NS: Non-Significant; *: Significant at 5\% level;

$* *$ : Significant at $1 \%$ level 
Table.6 Economic analysis of Integrated Farming System (IFS) components before and after implementation of project (N=271)

\begin{tabular}{|c|c|c|c|c|c|c|c|c|c|c|c|c|c|c|c|c|c|c|c|c|c|}
\hline \multirow[b]{2}{*}{ Crop Component } & \multirow[b]{2}{*}{$\begin{array}{l}\text { Avg. } \\
\text { Land } \\
\text { Holding } \\
\text { (Acre.) }\end{array}$} & \multicolumn{8}{|c|}{ Before } & \multicolumn{8}{|c|}{ After } & \multirow{2}{*}{$\begin{array}{c}\text { Change } \\
\text { in yield } \\
(\%)\end{array}$} & \multirow{2}{*}{$\begin{array}{l}\text { Change } \\
\text { in } \\
\text { Income } \\
(\%)\end{array}$} & \multirow{2}{*}{$\begin{array}{l}\text { Emply. Gene. } \\
\text { in } \\
\text { (Mandays/ac.) }\end{array}$} & \multirow{2}{*}{$\begin{array}{l}\text { Emply. } \\
\text { Gene. of } \\
\text { Beneficiary } \\
\text { farmers } \\
\text { (Mandays) }\end{array}$} \\
\hline & & $\begin{array}{c}\text { Avg. } \\
\text { Yield } \\
\text { (Ql./ac.) }\end{array}$ & $\begin{array}{l}\text { Avg. yield } \\
\text { of } \\
\text { Beneficiary } \\
\text { farmers } \\
\text { (Ql./ac.) }\end{array}$ & $\begin{array}{c}\text { Price } \\
\text { (Rs./Ql.) }\end{array}$ & $\begin{array}{l}\text { Prod. } \\
\text { Cost/ac. } \\
\text { (Rs.) }\end{array}$ & $\begin{array}{l}\text { Prod. Cost } \\
\text { of } \\
\text { Beneficiary } \\
\text { farmers(Rs.) }\end{array}$ & $\begin{array}{l}\text { Gross } \\
\text { Income } \\
\text { (Rs./ac.) }\end{array}$ & $\begin{array}{l}\text { Net } \\
\text { Income } \\
\text { (Rs./ac.) }\end{array}$ & $\begin{array}{l}\text { B:C } \\
\text { Ratio }\end{array}$ & $\begin{array}{l}\text { Avg. } \\
\text { Yield } \\
\text { (Ql./ac.) }\end{array}$ & $\begin{array}{l}\text { Avg. yield } \\
\text { of } \\
\text { Beneficiary } \\
\text { farmers } \\
\text { (Ql./ac.) }\end{array}$ & $\begin{array}{c}\text { Price } \\
\text { (Rs./Ql.) }\end{array}$ & $\begin{array}{l}\text { Prod. } \\
\text { Cost/ac. } \\
\text { (Rs.) }\end{array}$ & $\begin{array}{c}\text { Prod. Cost } \\
\text { of } \\
\text { Beneficiary } \\
\text { farmers(Rs.) }\end{array}$ & $\begin{array}{l}\text { Gross } \\
\text { Income } \\
\text { (Rs./ac.) }\end{array}$ & $\begin{array}{l}\text { Net } \\
\text { Income } \\
\text { (Rs./ac.) }\end{array}$ & $\begin{array}{c}\text { B:C } \\
\text { Ratio }\end{array}$ & & & & \\
\hline Ragi (n1=185) & 0.50 & 6.50 & 3.25 & 1450.00 & 5200.00 & 2600.00 & 4712.50 & 2112.50 & 1.81 & 9.50 & 4.75 & 1900.00 & 8500.00 & 4250.00 & 9025.00 & 4775.00 & 2.12 & 46.15 & 91.51 & 82.00 & 41.00 \\
\hline Groundnut (n2=86) & 0.34 & 3.00 & 1.02 & 2200.00 & 2400.00 & 0816.00 & 2244.00 & 1428.00 & 2.75 & 4.00 & 1.36 & 2250.00 & 2568.00 & 873.12 & 3060.00 & 2186.88 & 3.50 & 33.33 & 36.36 & 77.00 & 26.18 \\
\hline Redgram* & & & & & & & & & & 1.50 & 0.75 & 3600.00 & 1000.00 & 500.00 & 2700.00 & 2200.00 & 5.40 & & & 6.00 & 3.00 \\
\hline Maize* & & & & & & & & & & 3.00 & 1.02 & 1450.00 & 1000.00 & 340.00 & 1479.00 & 1139.00 & 4.35 & & & 6.00 & 2.04 \\
\hline Total & & & & & & 3416.00 & 6956.50 & 3540.50 & 2.04 & & & & & 5963.12 & 16264.00 & 10300.88 & 2.73 & & 133.80 & & 72.22 \\
\hline $\begin{array}{l}\text { Livestock } \\
\text { Component }\end{array}$ & $\begin{array}{r}\text { Body liv } \\
\text { Ltrs/s } \\
\text { poultry c } \\
\text { co }\end{array}$ & $\begin{array}{l}\text { ive wt. or } \\
\text { sheep or } \\
\text { or pig or } \\
\text { ow }\end{array}$ & Price/kg & or Ltr & & Cost & $\begin{array}{c}\text { Gross } \\
\text { Income } \\
\text { (Rs.) }\end{array}$ & $\begin{array}{c}\text { Net } \\
\text { Income } \\
\text { (Rs.) }\end{array}$ & $\begin{array}{c}\text { B:C } \\
\text { Ratio }\end{array}$ & $\begin{array}{c}\text { Body l } \\
\text { Ltrs/ } \\
\text { poultry }\end{array}$ & $\begin{array}{l}\text { live wt. or } \\
\text { / sheep or } \\
\text { ry or pig or } \\
\text { cow }\end{array}$ & Price/k & g or Ltr & Cost & $\begin{array}{c}\text { Gross } \\
\text { Income } \\
\text { (Rs.) }\end{array}$ & $\begin{array}{c}\text { Net } \\
\text { Income } \\
\text { (Rs.) }\end{array}$ & $\begin{array}{c}\text { B:C } \\
\text { Ratio }\end{array}$ & $\begin{array}{c}\text { Change } \\
\text { in yield } \\
(\%)\end{array}$ & $\begin{array}{l}\text { Change } \\
\text { in } \\
\text { Income } \\
(\%)\end{array}$ & $\begin{array}{l}\text { Emply. Gene. } \\
\text { (Mandays) }\end{array}$ & $\begin{array}{l}\text { Emply. } \\
\text { Gene. of } \\
\text { Beneficiary } \\
\text { farmers } \\
\text { (Mandays) }\end{array}$ \\
\hline Cow (n1=135) & & & & & & & & & & 1750.00 & & 28.00 & & 19000.00 & 49000.00 & 30000.00 & 2.58 & & & & 240.00 \\
\hline Sheep $(\mathrm{n} 2=136)$ & & & & & & & & & & 95.00 & & 400.00 & & 8000.00 & 38000.00 & 30000.00 & 4.75 & & & & 105.00 \\
\hline Total & & & & & & & & & & & & & & 27000.00 & 87000.00 & 60000.00 & 3.22 & & & & 345.00 \\
\hline Grand total & & & & & 3416.00 & & 6956.50 & 3540.50 & 2.04 & & & & & 32963.12 & 103264.00 & 070300.88 & 3.13 & & 133.80 & & 417.22 \\
\hline
\end{tabular}




\section{Relationship between personal, psychological and socio-economic characteristics of respondents with their livelihood security}

The findings in the Table 4 imply that 11 out of 18 characteristics found to have positive and significant relationship with livelihood security. The characteristics such as land holding, cropping pattern, livestock possession, cosmopoliteness, innovativeness, extension participation, social participation, management orientation, training undergone, willingness towards IFS and access to resources exhibited positive and significant relationship with farmers livelihood security. The positive and significant relationship between land holding and cropping pattern with livelihood security might be due to that all respondents selected for project having minimum land holding of 1.00 to 5.00 acre this in turn influences livelihood security of the respondents. Farmers mainly depends on farming for their livelihood, increasing the cropping intensity gives better income and livelihood security. Through project seed material, planting material and livestock components were supplied at free of cost and respondents engaged in rearing of livestock as subsidiary occupation for additional income. Hence, livestock possession had positive and significant relationship with livelihood security of respondents. The positive and significant relationship between cosmopoliteness and innovativeness with livelihood security might be due to the fact that cosmopoliteness of respondents helps to provide an exposure to outside the world which might have helped to get opportunity to obtain better livelihood. Individual is closely associated with change, adopting innovative ideas and practices leading to security for the life. The positive and significant relationship between extension participation and social participation with livelihood security might be due to that extension participation of respondents might have enhanced their knowledge about different technologies available for better farming. This might have resulted in increasing the income and livelihood security. The results could be attributed to the fact that the participation of individuals in formal and informal organizations or groups, broadens one's sphere of interest and increases one's information concerns. Interaction opportunity helps to share ideas and refine their interpretation of situation. Also, exposure to varied persons heightens the aspirations of the individuals with better understanding of reality of situation and finally helps in estimation of gap between - what is and what ought to be. The exposure of respondents to training programmes increases their confidence level and skills to do varied works as a result earnings also increases. Hence, training received had positive and significant relationship with livelihood security of respondents. It is clear from the results that there was a positive and significant relationship between willingness in agriculture and access to resources with livelihood security. As farmers mainly depends on farming, willingness to do agriculture, to utilization of available resources, which leads to higher productivity, profitability, generates employment and finally income of farm. This in turn influences livelihood security of respondents. The results obtained are similar to the findings of Mamathalakshmi (2013), Sujay Kumar (2018) and Harshitha et al., (2018).

Extent of contribution of personal, psychological and socio-economic characteristics to livelihood security of respondents

The regression test was applied to ascertain the contribution of independent variables to the livelihood security of respondents and the results are presented in Table 5. The results of 
multiple linear regression analysis showed that land holding, livestock possession, cosmopoliteness, innovativeness, extension participation, social participation, training undergone and access to resource had significantly contributed to livelihood security of respondents. The R2 value of 0.553 indicated that all 18 variables had contributed to the tune of 55.3 per cent of variation in livelihood security. The possible reasons might be that the personal and sociopsychological variables of respondents are the deciding factors of their livelihood security. These characteristics have synergic effects to one another, helping each other to have a major extent of contribution to the livelihood security. The findings are in conformity with the results obtained by Sujay Kumar (2018) and Harshitha et al., (2018).

\section{Income of respondents after implementation of project}

It is observed from Table 6 indicates that, after implementation of the project, the average yield of ragi increased by 46.16 per cent, groundnut increased by 33.33 per cent. The livestock components (cow and sheep) generate 345 mandays employment per year and provided additional net income of Rs. 60000. In 2018 reported that the average gross income of Rs. 103264 from both crop and livestock enterprises of IFS against Rs. 6956 before implementation of the project. In total a farmer could realize about Rs. 70300 net profit by adopting intercropping and livestock components in IFS. As such, for every one rupee investment under IFS they are getting 3.13 rupee income. Similar results reported by Uddin (2015) and Kamble Anand Shankar et al., (2017).

The findings of the present study revealed that the livelihood security improved from less satisfied to highly satisfied level (08.48\%), out of seven dimensions of livelihood security maximum increase was noticed in employment security (39.35\%). Further, respondents earned Rs. 3.13 income for every one rupee investment under IFS. Hence, encourage the farmers to practice IFS which helps to increase their livelihood by organising extension educational programmes by the concerned development organisations. The characteristics such as land holding, cropping pattern, livestock possession, cosmopoliteness, innovativeness, extension participation, social participation, management orientation, training undergone, willingness towards IFS and access to resources exhibited positive and significant relationship. Hence, concerned departments and organizations should give more emphasis towards amplification of these characteristics to enhance livelihood security of farmers practicing IFS.

\section{References}

Anonymous, 2018, Hand book on Social Welfare Statistics, Dept. of Social Justice and Empowerment, Ministry of Social Justice and Empowerment, Govt. of India, New Delhi. p. 46-47.

Harshitha, D., Madhu Prasad, V. L. and Sanjay Yadav, 2018. Correlates of livelihood Security of women headed households practicing family farming in Tumakuru district. Internatl. $J$. Agric.Sci., 15:6810-6812.

Jayanta Roy, 2012. Impact analysis of Mahatma Gandhi National Rural Employment Guarantee programme in Dhalai district of Tripura. M. Sc. (Agri.) Thesis, Univ. Agric. Sci., Bangalore.

Kamble Anand Shankar, L. N. Yogeesh, S. M. Prashant, P. Sheik Peer and B.K. Desai, 2017, Integrated Farming System: Profitable Farming to Small Farmers. Internatl. J. Curr. Microbiol. App. Sci6(10): 2819-2824.

Mamathalakshmi, N., 2013. An analysis of 
livelihood security among agricultural labourers in Karnataka. Ph.D. Thesis, Univ. Agric. Sci.,Bangalore.

Raksha, Rita Goel and Lali Yadav, 2012, Constraints faced by rural women in procurement and utilization of credit facilities in Hisar district. J. Res. ANGRAU, 40(4): 2935.

Rokonuzzaman, M., 2013, Training Needs of Tribal People Regarding Income Generating Activities. Indian Res. J. Extn. Edu., 13(2): 10-16.
Sujay Kumar, S., 2018. Analysis of integrated farming system (IFS) on the development of Scheduled Caste (SC) Farmers in Southern Karnataka. Ph.D. Thesis, Univ. Agric. Sci.,Bangalore.

Uddin, M. T., Khan, M. A. and Islam, M. M., (2015), Integrated Farming and its Impact on Farmers' Livelihood in Bangladesh. Saarc J. Agri., 13(2):6179.

\section{How to cite this article:}

Madhu Prasad, V. L., S. Chandrashaker and Sujay Kumar, S. 2021. Integrated Farming System in Chickballapura District- A Method to Improve Livelihood Security of Farmers. Int.J.Curr.Microbiol.App.Sci. 10(01): 3525-3534.

doi: https://doi.org/10.20546/ijcmas.2021.1001.416 